\title{
ПЕРЕВАГИ ВИКОРИСТАННЯ ОНЛАЙН-ФОРМ ЯК ЗАСОБУ ВИКЛАДАННЯ В ІНТЕРНАТУРІ
}

\author{
В. І. Кривенко, І. С. Качан, І. В. Непрядкіна, О. П. Федорова, \\ М. Ю. Колесник, С. П. Пахомова, Т. Ю. Радомська \\ Запорізький державний медичний університет
}

\begin{abstract}
У статті наведено результати аналізу ефективності використання онлайн-фрорм у процесі опанування дисципліни «внутрішні хвороби». Проведено педагогічний експеримент із включенням 46 лікарів-інтернів, які займалися на кафедрі в період 2016-2017 років. Встановлено, що використання онлайн-фрорм дозволяє підвищити ефективність навчального процесу за рахунок, по-перше, зменшення часу, який витрачається на обробку результатів опитування, i, по-друге, поліпшення рівня засвоєння матеріалу та «виживаності» знань лікарів-інтернів за допомогою наочного представлення результатів вихідного випробування і предметної дискусії з проблемних питань. Онлайн-опитування характеризується більшою об'єктивністю і, як наслідок, більш позитивним стимулюючим впливом на пізнавальну діяльність лікаря-інтерна. У запропонованій методиці перевірка виконання ситуаційних завдань виконується централізовано, за єдиними критеріями, що дозволяє з достатньою підставою судити про загальний ступінь ссрормованості відповідних знань та навиків, виявляти типові помилки і на цій основі корегувати та надалі вдосконалювати навчальний процес. Поєднання онлайн-опитування як форми перевірки з традиційними засобами контролю, а також із самоконтролем може сприяти виробленню реальної системи об'єктивної оцінки знань і реалізації головного завдання освітнього процесу — формуванню міцних знань і забезпеченню високої якості підготовки майбутніх фрахівців.
\end{abstract}

Ключові слова: дистанційна освіта, інтернатура, загальна практика - сімейна медицина, онлайн-фрорма, засоби навчання.

\section{ADVANTAGES OF ONLINE FORMS AS A MEANS OF TEACHING OF INTERNSHIP}

\author{
V. I. Krivenko, I. S. Kachan, I. V. Nepryadkina, O. P. Fedorova, \\ M. Yu. Kolesnik, S. P. Pakhomova, T. Yu. Radomskaya \\ Zaporizhzhya State Medical University
}

\begin{abstract}
The article deals with the results of the analysis of the effectiveness of using online forms in the process of mastering the discipline «internal diseases». A pedagogical experiment was conducted with the inclusion of 46 interns who were engaged in the department during the period 2016-2017. It was found that the use of online forms to improve the efficiency of the educational process at the expense of, firstly, reducing the time spent on processing of the survey results, and, secondly, the optimization of the material assimilation level and «survival» knowledge of medical interns using a visual representation the results of the initial test and the substantive discussion on problematic issues. The combination of the online interviewing as a form of testing with the traditional way of control, and with self-control, can lead to a real system of objective assessment of the knowledge and realization of the main task of the educational process - the formation of strong knowledge and provide high-quality training of future specialists.
\end{abstract}

Key words: distance education, internship, general practice — family medicine, online form, teaching aids. 


\title{
ПРЕИМУЩЕСТВА ИСПОЛЬЗОВАНИЯ ОНЛАЙН-ФОРМ КАК СПОСОБА ОБУЧЕНИЯ В ИНТЕРНАТУРЕ
}

\author{
В. И. Кривенко, И. С. Качан, И. В. Непрядкина, Е. П. Федорова, \\ М. Ю. Колесник, С. П. Пахомова, Т. Ю. Радомская \\ Запорожский государственный медицинский университет
}

\begin{abstract}
В статье представлены результаты анализа эфффективности использования онлайн-фрорм в процессе освоения дисциплины «внутренние болезни». Проведен педагогический эксперимент с включением 46 врачей-интернов, которые занимались на кафредре в период 2016-2017 годов. Установлено, что использование онлайн-фрорм позволяет повысить эффективность учебного процесса за счет, во-первых, уменьшения времени, затрачиваемого на обработку результатов опроса, и, во-вторых, оптимизации уровня усвоения материала и «выживаемости» знаний врачей-интернов с помощью наглядного представления результатов исходного испытания и предметной дискуссии по проблемным вопросам. Онлайн-опрос характеризуется большей объективностью и, как следствие, более выраженным положительным стимулирующим влиянием на познавательную деятельность врача-интерна. В предлагаемой методике проверка выполнения ситуационных задач выполняется централизованно, по единым критериям, что позволяет с достаточным основанием судить об общей степени овладения соответствующими знаниями и навыками, выявлять типичные ошибки и на этом основании корректировать, а в дальнейшем - совершенствовать учебный процесс. Сочетание онлайн-опроса как фрормы проверки с традиционными средствами контроля, а также с самоконтролем может способствовать выработке реальной системы объективной оценки знаний и реализации главной задачи образовательного процесса - фрормированию прочных знаний и обеспечению высокого качества подготовки будущих специалистов.
\end{abstract}

Ключевые слова: дистанционное образование, интернатура, общая практика - семейная медицина, онлайнформа, способы обучения.

Вступ. Поряд із традиційними методиками навчання як на до-, так і на післядипломному етапі сьогодні актуальними є дистанційні форми освіти $[1,4,6]$. Натепер існує необхідність у швидкому відновленні знань, використанні новітніх передових інформаційних технологій у процесі навчання. Викладач закладу вищої освіти всіма можливими способами намагається закріпити отримані знання на практиці, впроваджуючи новітні технології, дотримуючись тенденцій розвитку інформаційних і комунікаційних технологій [2]. Це необхідне для того, щоб максимально ефективно застосовувати інновації у своїй роботі та з усього різноманіття існуючих інструментів уміти обрати той, що дійсно відповідає потребам як суб’ єкту навчання, так і самого викладача.

У Запорізькому державному медичному університеті як основна використовується платформа «EDx», що дозволяє поєднати ефективні засоби структурованого надання інформації за розділами курсу з оптимальними формами контролю засвоєння матеріалу за певним фрагментом, темою або кредитом. Проте необхідно зазначити, що використання інформаційних технологій актуальне не тільки для самостійної роботи, а також для підвищення ефективності семінарів і практичних занять у процесі щоденної аудиторної роботи з лікарями-інтернами [5]. Зважаючи на те, що основним засобом навчання на післядипломному етапі є практична лікарська діяльність під контролем викладача, виникає необхідність інтенсифікації освітнього процесу в аудиторії відповідно до робочої програми шляхом раціонального використання часу як викладача, так і лікаря-інтерна, поряд із оптимізацією засвоєння об’ємного матеріалу, що не завжди відповідає відведеній кількості навчальних годин. Одним із засобів викладання, що може стати у нагоді, є онлайн-форми — зручні сервіси зворотного зв'язку в режимі реального часу з оперативним опрацюванням отриманих даних та наочним представленням результатів. Такий спосіб має ряд переваг перед традиційним. Він відрізняється високою оперативністю, продуктивністю процесу навчання і об’єктивністю результатів контролю знань, дозволяє проаналізувати якість підготовки лікарів-інтернів за великим колом різних питань, допускає можливість самоконтролю.

Сьогодні доступні багато варіантів створення форм в Інтернеті. Основними перевагами сервісу «Google Forms» є вільний безоплатний доступ до всіх ресурсів та засобів застосування, зручний інтуїтивний інтерфейс конструктора форм та простота в користуванні: для того, щоб почати роботу, необхідно мати аккаунт «Google». Враховуючи те, що провідним призначенням онлайн-форм є отримання даних, ці сервіси традиційно використовують 
для проведення опитувань та тестувань. У рамках вищої школи використання онлайн-опитування розглядається як одна з актуальних форм контролю якості підготовки, що дозволяє об’єктивно оцінити обсяг засвоєної тієї чи іншої навчальної дисципліни. Використання завдань різних видів дозволяє більш адекватно відповідати вимогам державного освітнього стандарту, сприяє поліпшенню організації і підвищенню якості навчального процесу.

Нами також апробовано аналогічні методики поточного та заключного контролю знань лікарівінтернів [3]. Проте в процесі застосування даного виду інформаційних технологій на кафедрі автори звернули увагу на те, що наочне представлення результатів опитування лікарів-інтернів у вигляді діаграм поряд із обговоренням проблемних питань, які випливають 3 аналізу трендів відповідей, дозволяє раціонально провести роботу над помилками, оптимізувати засвоєння матеріалу та зекономити час.

Мета роботи: аналіз ефективності використання онлайн-форм у процесі опанування дисципліни «внутрішні хвороби» лікарями-інтернами першого року навчання за фахом «загальна практика — ciмейна медицина».

Матеріали та методи дослідження. Проведено педагогічний експеримент із включенням 46 лікарів-інтернів першого року навчання за фахом «загальна практика - сімейна медицина», які займалися на кафедрі в період 2016-2017 років. Враховуючи, що максимальна кількість годин виділена для вивчення серцево-судинної патології, для аналізу засвоєння матеріалу використовували тему «Основні синдроми в кардіології». Зміст ситуаційних завдань відповідав програмі навчання та відображав найбільш значущі, важливі теми, вузлові проблеми.

Лікарі-інтерни випадковим способом були розподілені на 2 групи.

Під час аудиторної роботи 26 інтернів першої групи на власний смартфон отримали посилання, переходячи за яким з використанням мобільного Інтернету, мали відповісти на 30 питань у форматі ілюстрованих ситуаційних завдань, що були наведені в онлайн-формі. Час опитування не обмежувався, проводився хронометраж із зазначенням хвилин, що були витрачені на відповіді кожним із респондентів. Викладач у режимі онлайн мав можливість отримувати дані про кількість виконаних завдань. Після відправлення відповідей останнім представником групи, за допомогою стандартних інструментів аналізу результатів опитування у власному аккаунті «Google Forms» викладач виводив на великий аудиторний екран діаграми, що відображали, як саме на це питання відповіли учасники тестування. На наступному етапі проводилось обговорення кожного ситуаційного завдання з урахуванням тренду правильних / неправильних відповідей, при цьому до дискусії обов'язково залучалися лікарі-інтерни, які мали невірний результат за цим завданням. У цій частині дослідження також зазначали кількість отриманих правильних відповідей та час, що було витрачено викладачем на аналіз та обговорення результатів. У подальшому через 2 місяці після завершення заняття повторювали те ж саме тестування та знову реєстрували кількість вірно виконаних завдань для оцінювання «виживаності» знань.

У другій групі лікарів-інтернів на першому етапі проводили опитування з включенням тих самих 30 питань, але в традиційній формі на папері. Також визначали час, необхідний для завершення тестування. Після цього викладач перевіряв правильність виконання завдань з реєстрацією часу, витраченого на цей вид роботи. На наступному етапі перевірені роботи з помітками біля кожного завдання були роздані інтернам і проводилось обговорення кожного питання. Проте викладач не мав можливості приділити увагу невірним відповідям кожного, лікарі-інтерни також мали перед очами лише свої результати. Час обговорення вносився до протоколу дослідження. Через 2 місяці тестування повторювали, як і в першій групі.

Статистичну обробку проводили за допомогою пакету статистичних програм «Statistica 10.0» («StatSoft® Inc», США). Центральні тенденції описували як медіану та міжквартильний розмах у вигляді Ме (25 \% квартиль; 75 \% квартиль). Якісні показники характеризували абсолютною кількістю та частками, що виражали у відсотках. За необхідністю розраховували 95 \% довірчі інтервали (ДІ) відносної частоти. Відповідність кількісних даних нормальному розподілу визначали за критерієм Шапіро-Уїлка. Значущість відмінностей кількісних даних між двома незалежними групами визначали за критерієм Манна-Уїтні. Порівняння у залежних групах проводили за допомогою критерію Вілкоксона. Відносні величини аналізували, розраховуючи ДІ часток. Крім того, використовували критерій Мак-Немара для визначення значущості змін якісних показників у динаміці. 
Результати та їх обговорення. Визначено, що час, витрачений на виконання завдань у кожній із груп, був зіставний: відповідно 43 (32; 51) та 47 (30; 50) хвилин. Однак у першій групі було виявлено значне скорочення періоду перевірки робіт викладачем та аналізу отриманих результатів. Так, у лікарівінтернів першої групи, які відправляли результати з власних смартфонів, а викладач у той самий час в електронному кабінеті власного аккаунту миттєво в режимі онлайн отримував діаграми з даними по кожному з завдань, для аналізу та відображення результатів всіх 26 респондентів викладачу знадобилася лише 1 хвилина. На відміну від цього, для перевірки відповідей лікарів-інтернів другої групи на папері викладач витратив 37 хвилин (медіана часу для аналізу 1 роботи становила $1,4(1,2 ; 1,8)$ хвилин). Отримана відмінність очікувана, проте необхідно зазначити, що вона є об’єктивним підтвердженням ергономічної ефективності використання онлайнформ для контролю знань. Крім економії часу, логічно вказати на факт збереження витратних матеріалів, що були використані для підготовки бланків із завданнями. Тривалість обговорення результатів у двох групах не мала значущої різниці: 28 хвилин у першій і 32 хвилини у другій групі.

Особливої уваги заслуговує порівняння успішності вихідного опитування між групами та оцінка «виживаності» знань через 2 місяці. Частка лікарівінтернів, які здолали поріг 70 \% правильних відповідей на завдання, в першій групі при первинному випробуванні становила 61,5 \% (ДІ 41,6-81,4), у другій — 65,0 \% (ДІ 42,8-87,2). Медіани вірно виконаних завдань (із 30 можливих) виявилися рівними: 24 (22; 26) і 24 (22; 25) відповідно. Зважаючи, що нашою метою був не тільки контроль знань, а також підвищення рівня засвоєння матеріалу, велика увага приділялася розбору кожного питання за умови, що кожен з респондентів мав власні результати перед очима. Після проведення обговорення в першій групі лікарів-інтернів і наглядного представлення діаграм з відповідями на великому екрані та виділенням з масиву найбільш проблемних завдань, ми очікували отримати більш високий результат через 2 місяці. Наші сподівання виправдалися, відмінності в порівнянні з другою групою були значущими. Так, частка лікарів-інтернів з першої групи, які вірно відповіли на 70 \% завдань, зросла з 61,5 \% до 84,6 \%. За критерієм Мак-Немара зростання було статистично значущим ( $=0,006)$. Результати у респондентів 3 другої групи також покращилися, але не були значущими: частка інтернів, які здолали встановлений поріг, збільшилася на 10 \% (за критерієм Мак-Немара $\mathrm{p}=0,3)$. Аналогічні закономірності спостерігалися при аналізі медіан правильних відповідей: зареєстровано зростання 324 (22; 26) до 27 (26; 29) в першій та 324 (22; 25) до 25 (22; 25,5) у другій групі. Логічним вважаємо порівняння параметрів за критерієм Вілкоксона: була підтверджена значущість змін у першій групі ( $<<0,001)$, а в другій мали лише тенденцію, результат не досягнув встановленої статистичної достовірності $(\mathrm{p}=0,1)$.

Слід зазначити, що активізація навчальної функції онлайн-оцінювання може допомогти знизити стрес перед іншими формами контролю. Вона дозволяє інтернам своєчасно уточнити і повторити найбільш важливі аспекти навчального матеріалу, усунути «прогалини» в знаннях, отримати об’єктивну оцінку, проаналізувати власний приріст знань i, за бажанням, порівняти їх із знаннями інших. Вимоги завдання, умови його проведення та інтерпретація результатів однакові для всіх. Отже, суб'єктивна складова оцінювання зводиться до мінімуму, що дозволяє інтерну реально співвідносити свій успіх або неуспіх з доданими зусиллями, а не з суб’ єктивною думкою або відношенням викладача. Тобто обгрунтоване використання онлайнтестування допомагає майбутньому лікарю більш чітко орієнтуватися в навчальному матеріалі, мати об’єктивне уявлення про власні успіхи і промахи, своєчасно ліквідувати недоліки в підготовці.

Висновки. Онлайн-форма $є$ не тільки зручним інструментом контролю знань, але й може вважатися засобом викладання.

Використання онлайн-форм дозволяє підвищити ефективність навчального процесу за рахунок, поперше, зменшення часу, що витрачається на обробку результатів опитування, i, по-друге, поліпшення рівня засвоєння матеріалу та «виживаності» знань лікарів-інтернів за допомогою наочного представлення результатів вихідного випробування та предметної дискусії з проблемних питань.

Онлайн-опитування характеризується більшою об’єктивністю i, як наслідок, більш позитивним стимулюючим впливом на пізнавальну діяльність лікаря-інтерна.

У запропонованій методиці перевірка виконання ситуаційних завдань виконується централізовано, за єдиними критеріями, що дозволяє з достатньою підставою судити про загальний ступінь сформованості відповідних знань і навиків, виявляти типові 
помилки і на цій основі корегувати та надалі вдосконалювати навчальний процес.

Поєднання онлайн-опитування як форми перевірки з традиційними засобами контролю, а також з самоконтролем може сприяти виробленню реальної системи об'єктивної оцінки знань і реалізації головного завдання освітнього процесу - формуванню міцних знань і забезпеченню високої якості підготовки майбутніх фахівців.

\section{Література.}

1. Ващенко В. Ю. Дистанционная форма обучения. История. Проблемы. Перспективы развития [Электронный ресурс] / В. Ю. Ващенко, В. А. Скляров, К. О. Козяков // Вісник Східноукраїнського національного університету імені В. Даля. - 2009. № 6E. - Режим доступу : http://www.nbuv.gov. ua/e-journals/vsunud/2009-6E/Index.htm.

2. Впровадження дистанційної освіти на кафедрі сімейної медицини і терапії / В. М. Ждан, М. Ю. Бабан, М. В. Ткаченко [та ін.] // Медична освіта. — 2017. T. 73, № 1. - С. 19-22.

3. Колесник М. Ю. Використання онлайн-форм для контролю знань лікарів-інтернів / М. Ю. Колесник, I. С. Качан // Сучасні підходи до вищої медичної освіти в Україні (з дистанційним під’єднанням ВМ(Ф) НЗ України за допомогою відеоконференцзв'язку) : матеріали XIV Всеукраїнської науково-практичної конференції з міжнародною участю, присвяченої 60-річчю ТДМУ (Тернопіль, 18-19 травня 2017 р.). — Тернопіль : ТДМУ, 2017. — Т. 2. — C. 246-247.

4. Про затвердження Положення про дистанційне навчання : наказ Міністерства освіти і науки України від 25.04.2013 № 466 [Електронний ресурс] / Верховна Рада України. — Режим доступу : http://zakon5. rada.gov.ua/laws/show/z0703-13.

5. Рижов В. А. Моделі знань у системах дистанційного навчання / В. А. Рижов // Клінічна інформатика і телемедицина. — 2010. — № 7. — С. 133-139.

6. Nasiri F. Postgraduate research supervision at a distance: a review of challenges and strategies / F. Nasiri, F. Mafakheri // Studies in higher education. — 2015. — Vol. 40, No. 10. - P. 1962-1969.

\section{References.}

1. Vashchenko, V. Yu., Sklyarov, V. A., \& Kozyakov, K. O. (2009). Distantsionnaya forma obucheniya. Istoriya. Problemy. Perspektivy razvitiya [Distance learning. History. Problems. Development prospects]. Visnik Skhidnoukrains'kogo natsional'nogo universitetu imeni V. Dalya (Bulletin of the East Ukrainian National University named after V. Dal), 6E. Retrieved from: http://www.nbuv.gov.ua/e-journals/vsunud/2009-6E/ Index.htm.
2. Zhdan, V. M., Baban, M. Yu., Tkachenko, M. V., Volchenko, G. V., Kitura, Ye. M., Shilkina, L. M., \& Lebid', V. G. (2017). Vprovadzhennya distantsiinoi osviti na kafedri simeinoi meditsini i terapii [Introduction of distance education at the Department of family medicine and therapy]. Medichna osvita (Medical education), 73(1), 19-22.

3. Kolesnik, M. Yu., Kachan, I. S. (2017). Vikoristannya onlain-form dlya kontrolyu znan' likariv-interniv [Using online forms to control the knowledge of interns]. In Suchasni pidkhodi do vishchoi medichnoï osviti v Ukraini (z distantsiinim pid'ednannyam VM(F)NZ Ukraini za dopomogoyu videokonferentszv'yazku) (Modern approaches to higher medical education in Ukraine (with remote connection of HM(F)EI of Ukraine through video conferencing)): materials of the XIV International Scientific and Practical Conference with international participation dedicated to the 60th anniversary of TSMU (Ternopil, May 18-19, 2017) (Vol. 2, pp. 246-247). Ternopil’: TSMU.

4. Pro zatverdzhennya Polozhennya pro distantsiine navchannya [On approval of the Regulation on distance learning]: decree of the Ministry of Education and Science of Ukraine No. 466. (2013, April 25). Retrieved from The Verkhovna Rada of Ukraine website: http:// zakon5.rada.gov.ua/laws/show/z0703-13.

5. Rizhov, V. A. (2010). Modeli znan' u sistemakh distantsiinogo navchannya [Models of knowledge in distance learning systems]. Klinichna informatika i telemeditsina (Clinical informatics and telemedicine), 7, 133-139.

6. Nasiri, F., \& Mafakheri, F. (2015). Postgraduate research supervision at a distance: a review of challenges and strategies. Studies in higher education, 40(10), 19621969. doi: org/10.1080/03075079.2014.914906. 